\title{
APPLIED TECHNOLOGICAL DIRECTION OF POWER PLANT ASH AND SLAG WASTE MANAGEMENT WHEN KUZNETSK BITUMINOUS COAL IS BURNED
}

\author{
Snejana A.Lihach ${ }^{1,}{ }^{*}$, Maria V. Grishchernko ${ }^{1}$, Roman N. Kulesh ${ }^{1}$, Vitali M. Lebedev ${ }^{2}$, and \\ Ksenia Y. Orlova ${ }^{1}$ \\ ${ }^{1}$ Tomsk Polytechnic University, 634050 Tomsk, Russia \\ ${ }^{2}$ Omsk State Transport University, 644046 Omsk, Russia
}

\begin{abstract}
Currently a lot of power plants have a problem with storage of coal combustion solid by-products (ash and slag). Holding capacity of existing power plants available ash dumps were enlarged and modernized repeatedly. Many plants have two or even three of them. Today new ash dump construction is economically inconvenient due to need to assign new plots of land and their inconveniently big distance from a plant, which increase ash and slag transportation expenses. The goal of our research work is to find promising directions for ash and slag waste mass utilization based on Kuznetsk bituminous coals experimental data on ultimate composition and properties. The experimental research of ash, slag and their mixture samples from ash dumps brought us to conclusion that the most promising direction for these materials application in large quantities is construction industry including road construction. Be-sides, we lined up some other directions for ash, slag, and ash and slag mixture possible application. These directions might not provide mass utilization but they are promising from a point of view of the researched waste properties.
\end{abstract}

\section{Introduction}

Constantly developing modern technologies and growing cities demand increase of electric and thermal energy supply. Power industry plants are quite capable to provide those in fullscale working with high force. Over the years power plants increase their output. Fuel volumes grow considerably, and as consequence waste volume grow as well.

\section{Review}

Power plants waste is an ash and slag mixture. It forms during several processes: when fuel is burned in steam boilers; when smokestack exhaust gases pass through fly-ash collectors; and when water necessary to awash the mixture into com-mon hydraulic removal channel

\footnotetext{
* Corresponding author: snejka.lix@yandex.ru
} 
asses through. Then formed pulp from those channels with the use of pumps comes into an ash dump. Ash dump is a quite large piece of land with a cup-like hollow and an extended edge around the perimeter - border levee. Ash dump bottom and border levee are usually made of medium fine gravel and areneceous filler mixture.

According to Energy Forecasting Agency yearly output of ash and slag waste in Russia is about 30 million tons, and over 1,5 billion tons are ac-cumulated up to date. That said ash dumps capacity of 115 coal burning plants out of 172 is almost exhausted [1].

Ash and slag mixture flow to ash dump after it is being completely filled up (with mound formation) is totally unacceptable because there is a possibility of dusting during ash dump drying process. This might have a negative impact on objects within ash dump controlled access area: residential complexes, water bodies and other [2]. That is why ash and slag mixture disposal is so up to date problem for Russian thermal power plants nowadays.

Land assign for new ash dumps is rarely supported by City Halls on grounds of existing plots of land assignment (for residential construction, for agriculture use etc.), and also on grounds of water body locations being there. If ash dump will be located on such a land, it would be impossible to keep up of controlled access area, i.e. minimum distance from ash dump border levee to residential and nature objects. The distance is a subject to Russia Land Code. Based on the above we think that the best solution to the problem is ash and slag use in all possible ways with their removal from ash dumps. Therefore ash dump available capacity will increase.

There are a number of ways to dispose ash and slag mixture: as a compounding material in concrete, brick, ceramic production, as a filler for worked-out coal open cut during its restoration, as a material during road construction, as an ice covering material in winter time, as a material for agriculture use $[2,3]$. However the most technologically reasonable and fast way to utilize ash and slag mixture - its application in road construction industry [4].

For possibility to use ash and slag waste in construction they must be certified as a construction material. Only after the certification it will classified as a raw material for industrial applications and could be called ash and slag materials (ASM). In order to get that done ash and slag waste go through sedimentation process, separation from fly-ash light fraction if any and drying. Then necessary analysis of ash and slag mixture characteristics, their compatibility to standards and of execution permission documentation takes place.

\section{Research description}

In the presented research we used ASM from Kuznetsk bituminous coal combustion as a sampling material to determine its applicability in road construction. During the research we studied initial fuel and ash and slag material characteristics found in laboratory setting (table 1).

While analysing table 1 we came to conclusion that researched ash in mostly identical to natural materials used in construction, for instance sand with $\mathrm{SiO}$ as a base, low calcium oxide content and spiked with aluminium oxides. The ash composition makes it a promising material from aluminium sulfate and corundum production point of view which used in waste water treatment and several areas of chemical industry. Besides it makes the researched ash also a promising material in terms of aluminosilicate microspheres production. Those are used in oil and gas, chemical, construction and machine-building industries $[5,6]$. 
Table 1. Experimental research results of initial coal and ash after its combustion.

\begin{tabular}{|c|c|c|c|}
\hline No. & \multicolumn{2}{|r|}{ Descriptors } & Range \\
\hline 1 & \multicolumn{2}{|l|}{ Grade of fuel } & $1 \mathrm{CC}$ \\
\hline 2 & \multirow{7}{*}{ 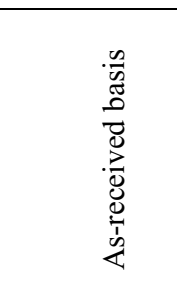 } & $\mathrm{W}^{\mathrm{p}}, \%$ & 9.0 \\
\hline 3 & & $\mathrm{~A}^{\mathrm{p}, \%}$ & 18.2 \\
\hline 4 & & $\mathrm{~S}_{\mathrm{K}}^{\mathrm{p}}+\mathrm{S}_{\mathrm{op}}^{\mathrm{p}}, \%$ & 0.3 \\
\hline 5 & & $\mathrm{C}^{\mathrm{p}}, \%$ & 61.5 \\
\hline 6 & & $\mathrm{H}^{\mathrm{p}}, \%$ & 3.7 \\
\hline 7 & & $\mathrm{~N}^{\mathrm{p}}, \%$ & 1.5 \\
\hline 8 & & $\mathrm{O}^{\mathrm{p}}, \%$ & 5.8 \\
\hline 9 & \multicolumn{2}{|c|}{ Lower calorific value, ccal $/ \mathrm{kg}$} & 5700 \\
\hline 10 & \multicolumn{2}{|c|}{ Ash on the dry basis, $\%$} & 20.0 \\
\hline 11 & \multicolumn{2}{|c|}{ Maximum humidity, \% } & -- \\
\hline 12 & \multicolumn{2}{|c|}{ Maximum ash content, $\%$} & 25.0 \\
\hline 13 & \multicolumn{2}{|c|}{ Maximum sulfur content, $\%$} & -- \\
\hline 14 & \multicolumn{2}{|c|}{ Hygroscopic moisture, $\%$} & 1.6 \\
\hline 15 & \multicolumn{2}{|c|}{ Normalized moisture, $\% * 10^{3} \mathrm{~kg} / \mathrm{ccal}$} & 1.58 \\
\hline 16 & \multicolumn{2}{|c|}{ Normalized ash content, $\% * 103 \mathrm{~kg} / \mathrm{ccal}$} & 3.20 \\
\hline 17 & \multicolumn{2}{|c|}{ Dry ash free volatile-matter content, $\%$} & 30.0 \\
\hline 18 & \multirow{3}{*}{ 至 } & Initial deformation & $1100-1500$ \\
\hline 19 & & Weaking initiation & $1240-1500$ \\
\hline 20 & & Fluid initiation & $1280-1500$ \\
\hline 21 & \multirow{8}{*}{ 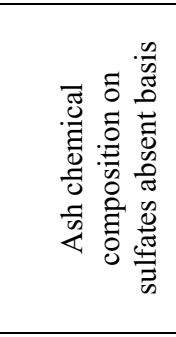 } & $\mathrm{SiO}_{2}, \%$ & 60.0 \\
\hline 22 & & $\mathrm{Al}_{2} \mathrm{O}_{3}, \%$ & 20.8 \\
\hline 23 & & $\mathrm{TiO}_{2}, \%$ & 0.83 \\
\hline 24 & & $\mathrm{Fe}_{2} \mathrm{O}_{3}, \%$ & 10.4 \\
\hline 25 & & $\mathrm{CaO}, \%$ & 2.9 \\
\hline 26 & & $\mathrm{MgO}, \%$ & 1.4 \\
\hline 27 & & $\mathrm{~K}_{2} \mathrm{O}, \%$ & 2.61 \\
\hline 28 & & $\mathrm{Na}_{2} \mathrm{O}, \%$ & 0.6 \\
\hline
\end{tabular}

ASM is classified as a "virtually non-hazardous waste" which is the fifth class based on negative environmental dimension. It also falls into the first class based on effective specific activity of natural radioactive nuclides, $A_{\text {eff }}$ (effective specific activity of natural radioactive nuclides is three times lower than maximum). It means that the re-searched ASM could be used in construction and road structures without limitations.

Requirements for ash and dump materials used in road construction are set according to regulatory documents [7]. In compliance with these documents cold resistance is the main criteria for ash and slag materials evaluation. Such-like international research use ASM samples mechanical characteristics in the induration process as the main applicability criteria [8].

Cold resistance is determined in laboratory setting and characterized by specific frost heave $\mathrm{K}_{\text {frost heave }}$. It is ratio of vertical strain blow up in the process of sample freezing to its initial height ex-pressed as a percentage. According to the con-ducted experiments specific frost heave of carbonaceous ash and slag materials is no more than $3 \%$. Therefore these materials will be intended to be described as a slightly rebound [7]. Such ash and slag mixtures might be used for earth roadbed embankment erection and roadbed surfacing with almost no limitations. 


\section{Conclusion}

In conclusion we would like to note that problem of Russian power plant ash dump total capacity decrease in one of the most essential topics at the moment. If no action would be taken to solve the problem, ash dumps would have been filled out completely within next 5-10 years. Whereas characteristics of the researched ash and slag material allow to use them in construction industry for road pavement building without road bed quality deviation, and in different areas of chemical industry.

\section{References}

1. I.S. Kojuhovsky, Y.K. Celikovsky, Energ. 6 (2011)

2. J. Hot, M. Sow, C. Tribout, M. Cyr, Constr. Build. Mat. 110 (2016)

3. N. Nordin, M.M.A.B. Abdullah, M.F.M. Tahir, A.V. Sandu, K. Hussin, Int. J. Cons. Sc. 7 (2016)

4. M. Pasetto, N. Baldo, Constr. Build. Mat. 108 (2016)

5. A.S. Inozemtsev, E.V. Korolev, Ind. Civil Eng. 10 (2013)

6. Z.R. Ismagilov, N.V. Shikina, N.V. Zhuravleva, R.R. Potokina, N.A. Rudina, V.A. Ushakov, T.N. Teryaeva, Sol. Fuel Chem. 49 (2015)

7. Engineering instructions for application of fly-ashes and ash and slag mixtures from various solid fuel combustion for earth roadbed, road base and road surface building (ISCS 185-75.)

8. V.N. Castaldelli, J.C.B. Moraes, J.L. Akasaki,J.L.P. Melges, j. Monzó, M.V. Borrachero, L. Soriano, J. Payá, M.M. Tashima, Fuel 174 (2016) 